\title{
Trapping for Sirex Woodwasp in Brazilian Pine Plantations: Lure, Trap Type and Height of Deployment
}

\author{
Elder S. P. Batista ${ }^{1} \cdot$ Richard A. Redak $^{2}$ • \\ Antonio Carlos Busoli ${ }^{1}$. Mariane B. Camargo ${ }^{3}$. \\ Jeremy Dean Allison ${ }^{4}$
}

Revised: 8 March 2018 /Accepted: 15 March 2018 /

Published online: 20 March 2018

(C) Springer Science+Business Media, LLC, part of Springer Nature 2018

\begin{abstract}
The Sirex woodwasp, Sirex noctilio (Hymenoptera: Siricidae) is considered a secondary pest of pine in its native range but has caused considerable economic losses in pine plantation forests in the southern hemisphere. In Brazil, trap trees are the primary tool used for early detection purposes but these are costly, labor-intensive to install and require stressing trees by herbicide application. Flight intercept traps baited with synthetic blends of host volatiles are an attractive alternative but have performed poorly in some settings. This study was carried out to look for alternatives to trap trees for use in Brazilian pine plantations for early detection of $S$. noctilio. Four field experiments were conducted in two consecutive flight seasons (2015-16 and 2016-17), in planted loblolly pine (Pinus taeda) stands, to compare captures among flight intercept traps baited with different lures, deployed at different heights and among different intercept trap designs. Two experiments compared different host volatile lures and a significant treatment effect was observed in one. No effect of trap design or height was observed.
\end{abstract}

Keywords European woodwasp · survey and detection · woodborer · invasive species

Elder S. P. Batista

elderspb@gmail.com

1 Departamento de Fitossanidade, Universidade Estadual Paulista, Unesp/FCAV, Via de Acesso Prof.

Paulo Donato Castellane, s/n, Jaboticabal, SP 14884-900, Brazil

2 Department of Entomology, University of California, Riverside, CA 92521, USA

3 Klabin Florestal, Av. Brasil, 26 - Harmonia, Telêmaco Borba, PR 84275-00, Brazil

4 Natural Resources Canada, 1219 Queen Street East, Sault Ste Marie, ON P6A 2E5, Canada 


\section{Introduction}

Attractant-baited intercept traps are widely used in forest insect pest management surveys and detection programs [e.g., Early Detection and Rapid Response Program (Rabaglia et al. 2008)], to predict population trends of pest species [e.g., the southern pine beetle (Billings and Upton 2010)], to document the distribution of non-native and outbreak species, and to evaluate the impact of management efforts (Myers et al. 2000; Liebhold and Tobin 2008). Numerous trap design features can influence the abundance and diversity of forest insects captured. These include intercept trap type, type of collection cup or killing agent, trap surface treatment, modifications to the collection column and the visual cues presented (McIntosh et al. 2001; Allison et al. 2014; Dodds et al. 2015; Allison and Redak 2017). A large number of studies have quantified the impact of trap design and deployment methodology on the capture of forest Coleoptera and some patterns in trap design are beginning to emerge (Allison and Redak 2017). Regardless, existing strategies are almost always insect-specific and their breadth of utility unknown. Consequently, for numerous pest species, operational survey and detection tools do not exist and/or require further development.

The Sirex woodwasp, Sirex noctilio (Fabricius 1793) (Hymenoptera: Siricidae) is native to Eurasia and North Africa but has accidentally been introduced to several countries in the southern hemisphere and more recently into North America (both Canada and the USA, see Slippers et al. 2012). Although considered a secondary pest of pine species in its native range, the Sirex woodwasp has caused considerable economic losses in pine plantation forests in the southern hemisphere (Hurley et al. 2007). The negative impact of this invasive pest on plantation forests has been mitigated by the development of silvicultural treatments that reduce tree stress and by release of several biological control agents (most notably the nematode Deladenus siricidicola).

First detected in Brazil in 1988, as of 2012, S. noctilio had a distribution of ca. 450,000 ha in the Southern and Southeast regions of Brazil, and some estimates suggest that annual losses caused by this insect could reach 30 million US dollars (Iede et al. 2012). In response to the establishment of $S$. noctilio in Brazil, the National Fund for Woodwasp Control (FUNCEMA) was established with the primary objective of developing a management strategy for $S$. noctilio in Brazilian pine plantation forests. Brazilian management programs involve the silvicultural practice of thinning to promote tree vigor and resistance to attack, and biological control of the wasp. Surveillance tools are used to time thinning operations as thinning can result in increased susceptibility to attack if performed during the S. noctilio flight period (Iede et al. 2012). Similarly, the release of biological control agents relies on surveillance, because releases are most effective when they occur before wasp infestations reach high levels. Surveillance of S. noctilio in Brazil relies on the use of trap trees that have been stressed by herbicide application (Penteado et al. 2002). These trees are relatively attractive to colonizing female wasps. Although effective, the use of herbicide-stressed trap trees is labor intensive, expensive, and the use of herbicides in forest settings is not widely accepted by the general public.

Alternative surveillance techniques exist and have been used to monitor populations of $S$. noctilio in its invaded range. Ground and aerial surveys have been used extensively in Australia, South Africa and South America (Carnegie et al. 2005; Beéche et al. 
2012; Hurley et al. 2012; Klasmer and Botto 2012). Additionally, remote sensing has been tested for use to detect differences in the spectral reflectance of stressed and healthy trees. Unfortunately, like aerial surveys, it is unable to discriminate between Sirex stressed/attacked trees and trees with altered spectral properties for reasons unrelated to Sirex infestations. Additionally, both remote sensing and aerial surveys have poor detection rates for low density $S$. noctilio populations, particularly those limited to understory trees (Haugen et al. 1990; Carnegie and Bashford 2012).

At low densities, $S$. noctilio almost exclusively infests stressed trees (Neumann and Minko 1981; Dodds et al. 2010; Haavik et al. 2016). This observation was the impetus for the development of trap trees for survey and detection of S. noctilio (Madden 1971; Madden and Irvine 1971; Neumann et al. 1982). It also suggests that stressed trees are preferentially attacked, and that attack is mediated by visual and/or olfactory cues associated with stressed pines. Several studies have attempted to identify volatiles that mediate attraction of $S$. noctilio females to stressed pines (Simpson 1976; Simpson and McQuilkin 1976). Field trials in Australia observed that pines treated with semiochemicals designed to represent a stressed pine had an incidence of attack four times greater than untreated pines (Bashford and Madden 2012). Although commercial semiochemical lures have been developed and are used operationally, they have not performed well in some cases. For example, in the southeastern US, native Siricidae (e.g., not S. noctilio which is not yet present there) are trapped in higher numbers in traps baited with fresh foliage and branches than commercially-available lures (Barnes et al. 2014). Although no direct comparisons between trap trees and traps baited with commercial Sirex lures were made, two North American studies have concluded that trap trees are superior to traps baited with commercial Sirex attractants (Zylstra et al. 2010; Barnes et al. 2014). Johnson et al. (2013) compared trap trees and semiochemical-baited traps for survey of Sirex nigricornis. Although statistically there were few differences among trap-tree and baited-trap treatments, trap captures were always higher in baited traps, and the authors concluded that semiochemical-baited traps were superior to trap trees. Hurley et al. (2015) report that unlike in North America (e.g., Dodds and de Groot 2012), commercial Sirex lures work well in South Africa and speculate that differences in population density among locations (high in South Africa; low in North America) may explain the variation in performance. It is also possible that the variation in performance is a result of qualitative differences between lures used in South Africa and North America.

Studies looking at the effect of trap type have also reported somewhat variable results with some reporting an effect of trap type (McIntosh et al. 2001; Bashford 2008; Allison and Redak 2017) on captures of woodwasps, while other studies have not detected difference in trap type (e.g., Haavik et al. 2014; Barnes et al. 2014; Hurley et al. 2015). Differences among studies in treatments and experimental protocols likely contribute to the varied patterns of treatment effects. This study was carried out in two consecutive years (2015-16) and designed to test the effectiveness of different lures, trap types, and heights of trap deployment on the capture of $S$. noctilio in Brazilian pine plantation forests.

\section{Material and Methods}

Multiple field trapping experiments were conducted to examine the effect of trap design, trap height and different sources of host volatiles on the number of individual 
female $S$. noctilio captured in flight intercept traps. All field experiments were deployed in loblolly pine (Pinus taeda) stands with varying ages, sizes and levels of S. noctilio attack (see Table 1), estimated by sequential sampling methods according to Penteado et al. (2002). In all experiments traps were hung from a rope tied between two adjacent trees. Each trap was at least $1 \mathrm{~m}$ from the closest tree and the top of each trap was ca. $2 \mathrm{~m}$ above ground (except for the $8 \mathrm{~m}$ treatment traps in Experiment 4, which were $8 \mathrm{~m}$ above ground). All traps were at least $20 \mathrm{~m}$ from the closest trap and $15 \mathrm{~m}$ from the stand boundary. All traps were equipped with collection cups filled with $100 \mathrm{ml}$ of $25 \%$ salt solution and a few droplets of scentless detergent (Ipêß). Collections were performed approximately every 2 weeks on 03-Nov, 16-Nov, 30-Nov, 07-Dec, 21Dec 2015 and 04-Jan 2016 in 2015-16 (Experiments 1 \& 3) and 15-Nov, 30-Nov, 08Dec, 22-Dec 2016, 05-Jan, 18-Jan and 08-Feb 2017 in 2016-17 (Experiments 2, 3 \& 4). At each collection date, the salt solution and host material lures were replaced. The turpentine and artificial lures were replaced once during Experiment 2, on 05-Jan 2017. Captured material was returned to the laboratory where it was processed, and all $S$. noctilio were identified, sexed and counted.

\section{Effect of Natural Sources of Host Material}

Experiment 1 was conducted, from 20-October, 2015 to 4-January, 2016 and tested whether there were any differences in $S$. noctilio captures among panel intercept traps baited with five different sources of host material lures: 1) Pinus taeda, 2) P. elliotti, 3) P. eliliodurensis [a hybrid of $P$. elliottii and P. caribaea hondurensis (hereafter Hybrid 1)], 4) P. tecunumanii X P. caribaea hondurensis hybrid (hereafter Hybrid 2), and 5) blank with no host material. Host material was incorporated into each lure through the use of mesh bags containing host foliage and small pieces of the main bole split into billets with the bark on of each species evaluated. The species/hybrids evaluated were used, because they are the main commercial pine planted in Brazil and are susceptible to $S$. noctilio attack (see below for a description of lure preparation). Panel traps constructed from $3 \mathrm{~mm}$ corrugated plastic by Cartonale Ind. e Benef. de Materiais Plásticos Ltda., Santana do Parnaíba, SP, Brazil (the same design and dimensions as the panel trap produced by ConTech Enterprises Inc., Victoria, BC, Canada) were assembled in the field and used for all treatments (see Fig. 1). At each of two sites, traps were deployed in a $5 \times 5$ grid consisting of five replicate blocks with one of each of the five bait treatments. Each trap was at least $20 \mathrm{~m}$ from its nearest neighbor.

Table 1 Loblolly pine (Pinus taeda) stand traits where trapping experiments were deployed

\begin{tabular}{llll}
\hline Experiment & Stand age (years) & Stand size (ha) & Sirex attack level (\%) \\
\hline 1 & 14 & 13 & 3.5 \\
2 & 11 & 56 & 9.0 \\
$3(2015 / 16)$ & 14 & 33 & 5.0 \\
$3(2016 / 17)$ & 11 & 56 & 9.0 \\
4 & 11 & 56 & 9.0 \\
\hline
\end{tabular}



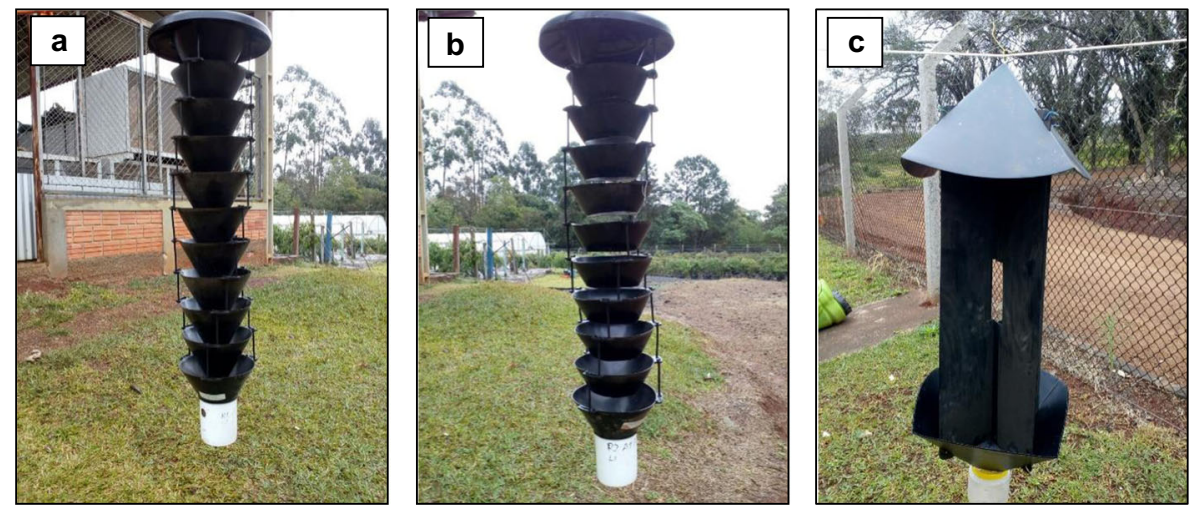

Fig. 1 Flight intercept traps types deployed. a Multiple funnel trap. b Modified multiple funnel trap. c Panel trap

\section{Comparison of Natural and Semi-Defined Sources of Host Volatiles}

Experiment 2 was conducted from 26-October, 2016 to 8-February, 2017 and, like Experiment 1, tested whether there were differences in $S$. noctilio captures in panel intercept traps baited with different sources of host material. Captures were compared in panel traps baited with: 1) P. taeda; 2) P. elliottii; 3) Hybrid 1; 4) turpentine; 5) commercial $S$. noctilio lure; and 6) blank traps with no lure. Host material lures (treatments 1, 2 and 3) were prepared as in Experiment 1. Slash pine (P. elliottii) turpentine was provided by Pinus Brasil Agro Florestal Ltda., Buri, SP, Brazil. Approximately $100 \mathrm{ml}$ of turpentine was placed in $300 \mathrm{ml}$ plastic bottles with $3 \mathrm{~cm}$ diameter top opening and no lid (Petty Embalagens Ltda., Jaboticabal, SP, Brazil). The bottles were hung outside the top funnel (i.e., under the overhang of the lid) to minimize rainwater falling into the open bottle. The release rate of turpentine from the bottles in the field is $\cong 0.5 \mathrm{~g} / \mathrm{d}$ (E. Batista, personal observation). Commercial $S$. noctilio lures were purchased from Alpha Scents Inc., West Linn, OR, United States. At each of two sites, traps were deployed in a $5 \mathrm{X} 6$ grid consisting of five replicate blocks with one of each of the six bait treatments. Again, each trap was at least $20 \mathrm{~m}$ from its nearest neighbor.

\section{Effect of Trap Design}

Experiment 3 was conducted, from 20-October, 2015 to 4-January, 2016 and then again from 26-October, 2016 to 8-February, 2017 and tested whether intercept trap design affected the number of female wasps captured in: 1) panel intercept traps; 2) commercial multiple funnel traps; and 3) modified multiple funnel traps (see Fig. 1 and Miller et al. 2013). Intercept panel traps were identical to those described above and the lure was made of $P$. taeda billets and foliage. Commercial multiple-funnel traps were purchased from ConTech Enterprises Inc. Modified multiple-funnel traps were multiple-funnel traps with the bottom $6 \mathrm{~cm}$ of each funnel removed in the laboratory [see Miller et al. (2013) for details] (Fig. 1). During both years at each of the two replicate sites, traps were deployed in a $5 \mathrm{X} 3$ grid consisting of five replicate blocks 
with one of each of the three trap design treatments. Each trap was at least $20 \mathrm{~m}$ from its nearest neighbor.

\section{Effect of Trap Height}

Experiment 4 was conducted from 26-October, 2016 to 8-February, 2017, and tested the effect of height of trap placement on $S$. noctilio captures in intercept panel traps baited with $S$. noctilio lures (purchased from Alpha Scents Inc.). Panel traps were deployed in pairs, hung from the same tree with one trap at $2 \mathrm{~m}$ and the other at $8 \mathrm{~m}$. At each of two replicate sites, trap pairs were deployed in a $5 \times 2$ grid consisting of five replicate blocks, each block with two traps (one at $2 \mathrm{~m}$ and one at $8 \mathrm{~m}$, each trap was at least $20 \mathrm{~m}$ from its nearest neighbor).

\section{Lure Preparation}

To obtain the host material used to make the lures for Experiments 1, 2 and 3, live trees were felled (see Table 2 for stand characteristics). Portions of the main bole were cut into $30 \mathrm{~cm}$ sections, which were then split longitudinally into halves. Approximately $165 \mathrm{~g}$ of foliage and ten billets (small pieces of the main bole split with the bark remaining) were used to produce a single lure of $1.5 \mathrm{~kg}$ (mesh bag containing foliage and billets). Fresh trees were cut every 2 weeks to produce fresh lures, and ca. five lures could be produced from a single cut tree. Lures $(0.5 \mathrm{~cm} \times 0.5 \mathrm{~cm}$ mesh size; $1 \mathrm{~m} \times$ $0.5 \mathrm{~m}$ bag size) were hung adjacent to the traps from the same rope on which the traps were suspended.

\section{Statistical Analyses}

In all experiments, captures were low resulting in many with less than five individuals per trap. Consequently, we were unable to analyze for the effect of stand or date regardless of experiment, and count data were pooled across date and stand for each treatment within each experiment. For each experiment, count data were analyzed using a standard G-test (Sokal and Rohlf 1981). For Experiments 1 and 2, no wasps were captured in the unbaited traps, and these treatments were not included in the analyses.

Table 2 Pine stands age and diameter at breast high (DBH) from were host material were collected to lure composition

\begin{tabular}{lll}
\hline Pine species / hybrid & Age (years) & Average DBH (cm) ${ }^{\mathrm{a}}$ \\
\hline Pinus taeda & 7 & 14 \\
Pinus elliottii & 7 & 14 \\
Hybrid 1 (P. elliottii x P. caribaea hondurensis) & 5 & 10 \\
Hybrid 2 (P. tecunumanii x P. caribaea hondurensis) & 5 & 10 \\
\hline
\end{tabular}

a only for felled trees 


\section{Results}

In total 202 S. noctilio individuals, all females, were captured and included in statistical analyses in experiments $1-4(51,80,36$, and 62 individuals respectively). Only Experiment 1, which compared different sources (i.e., Pinus spp.) of host material as a lure, showed a significant treatment effect (Table 3). Traps baited with lures containing Hybrid 1 consistently captured the most individuals. This pattern was not repeated in Experiment 2 in which a commercial lure was used. Experiments 2-4 (comparing lure, trap design and trap height, respectively) did not observe any treatment effects.

\section{Discussion}

This study examined the effect of trap type, height and different lures on the capture of $S$. noctilio in Brazilian pine plantations. The number of wasps captured was low, likely due in part to the low population levels in the stands selected for field trapping experiments. All of the stands had previously received applications of the nematode biological control agent Deladenus siricidicola. Despite the low capture numbers, this study observed a significant effect of lure treatment in Experiment 1 and that only traps baited with host material or commercial lure captured wasps.

Immature life stages of endophytic insects like $S$. noctilio cannot migrate among potential host plants. Consequently, their reproductive success is a function of the suitability of the host plant as perceived by host-seeking females, and the realized suitability of the host plant for larval development (Jaenike 1978; Thomson 1988; Mayhew 1997). Several studies have demonstrated that volatiles emitted by and characteristic of stressed pines are attractive to female S. noctilio (Simpson and McQuilkin 1976; Simpson 1976; Böröczky et al. 2012; Hurley et al. 2015). Trap trees are effective for monitoring low-density populations of $S$. noctilio (Madden 1971; Penteado et al. 2002). It has been demonstrated that herbicide-stressed trees emit larger quantities of volatiles and are more attractive to female $S$. noctilio than untreated

Table 3 Female individual Sirex noctilio captures by experiment and treatment

\begin{tabular}{|c|c|c|c|c|c|c|c|}
\hline \multicolumn{2}{|c|}{ Experiment 1} & \multicolumn{2}{|l|}{ Experiment 2} & \multicolumn{2}{|l|}{ Experiment 3} & \multicolumn{2}{|c|}{ Experiment 4} \\
\hline Lure & Captures & Lure & Captures & Design & Captures & Height & Captures \\
\hline P. taeda & 5 & P. taeda & 13 & Panel & 18 & $2 \mathrm{~m}$ & 27 \\
\hline P. elliottii & 11 & P. elliottii & 16 & Multiple funnel & 8 & $8 \mathrm{~m}$ & 35 \\
\hline Hybrid 1 & 22 & Hybrid 1 & 13 & Modified multiple funnel & 10 & & \\
\hline Hybrid 2 & 13 & Turpentine & 11 & & & & \\
\hline \multirow[t]{2}{*}{ Blank } & 0 & Commercial & 27 & & & & \\
\hline & & Blank & 0 & & & & \\
\hline Total & 51 & Total & 80 & Total & 36 & Total & 62 \\
\hline Expected & 12.75 & Expected & 16 & Expected & 12 & Expected & 31 \\
\hline G-test & 11.898 & G-test & 9.215 & G-test & 4.463 & G-test & 1.035 \\
\hline$p$ & 0.008 & $p$ & 0.056 & $p$ & 0.107 & $p$ & 0.309 \\
\hline
\end{tabular}


control trees (Böröczky et al. 2012). Field trapping studies have demonstrated that traps baited with synthetic host volatile blends capture more female $S$. noctilio than unbaited traps (Hurley et al. 2015). Barnes et al. (2014) observed that traps baited with fresh host material captured significantly more wasps than traps baited with commercial synthetic lures. Cumulatively, these results suggest that these types of volatiles are involved in the pre-alightment evaluation of potential oviposition sites by female $S$. noctilio. Postalightment evaluation of host suitability by females involves olfaction as well as evaluation of the host during probing of the host with the ovipositor. Females are reported to reject host pines with high osmotic pressure in the phloem tissue and accept those with low osmotic pressure (Coutts and Dolezal 1969; Madden 1974; Madden and Coutts 1979). Although no pines appear to be resistant to attack from $S$. noctilio (Ryan and Hurley 2012), differences in S. noctilio rates of attack and emergence among pine host trees have been observed (Dodds et al. 2010; Eager et al. 2011; Ryan et al. 2012; Zylstra and Mastro 2012; Ayres et al. 2014; Foelker 2016; Foelker et al. 2016; Haavik et al. 2017). Further, tree resistance is an important determinant of early instar larval survival (Haavik et al. 2015). Patterns of oviposition and larval development reported for $S$. noctilio in P. sylvestris, P. resinosa, P. banksiana and P. strobus do not support the hypothesis that female perceived suitability of host pines is adaptive for larval development.

Intercept traps baited with semiochemicals are among the most effective tools available for survey and detection of forest insects (Dodds et al. 2000; Brockerhoff et al. 2006; Johnson et al. 2013; but see Mercader et al. 2013). Numerous trap design factors have been reported to affect intercept trap performance for woodboring insects (Allison et al. 2014; Allison and Redak 2017) and several studies have compared trap designs for woodwasps, including $S$. noctilio. While some studies report no effect of trap design on capture (Costello et al. 2008; Barnes et al. 2014; Haavik et al. 2014; Hurley et al. 2015) others did observe an effect (McIntosh et al. 2001; Bashford 2008). Allison and Redak (2017) conducted meta-analyses of the literature on trapping bark beetles, woodboring insects and their associates and reported that panel traps captured significantly more woodwasps than multiple-funnel traps. Sarvary et al. (2015) observed that female $S$. noctilio could be captured by both black intercept traps and a clear jar trap when both were baited with the putative male-produced pheromone (Cooperband et al. 2012; but see Hurley et al. 2015). When traps were not baited with the putative pheromone, only the black intercept traps captured females. Most studies that have reported no effect of trap type, including this one, have captured few insects. It is possible that patterns of trap design effects are not independent of the olfactory stimuli presented with traps.

Madden (1974) looked at the distribution of oviposition drills by $S$. noctilio on the bole of standing trees successfully and unsuccessfully attacked. On trees successfully attacked, oviposition tended to occur randomly on the tree bole with a tendency to become uniform. Conversely, on trees that resisted attack, oviposition tended to become aggregated suggesting variation in suitability/acceptability within individual trees among tissues. While oviposition occurs along the entire bole in young (i.e., small) trees, it occurs between 3 and $14 \mathrm{~m}$ above ground in older trees (Neumann et al. 1982). Observational studies of female $S$. noctilio oviposition report that oviposition is initiated near the base of the tree and that subsequently females work their way up the bole ovipositing every 7.5-50 cm (Rawlings and Wilson 1949; Morgan and Stewart 
1966). Male $S$. noctilio are thought to form leks in the canopy of pine forests and that after emergence females are hypothesized to fly to the upper canopy where mating occurs (Morgan and Stewart 1966; Madden 1988). Cooperband et al. (2012) reported the identification of a male-produced pheromone that attracted both sexes in Y-tube olfactometer trials and speculated that it functioned to mediate lek formation among males and attraction of virgin females to leks. Consistent with this hypothesis, male wasps have been captured at higher heights than females, and when males were present in traps, females tended to be captured at higher heights (Martinez et al. 2014). Conversely, this study and Hurley et al. (2015) observed no effect of trap height on the capture of female $S$. noctilio. One potential explanation for the reported differences in trap height effects is that studies that report no effect of trap height baited traps with host volatiles while the study of Martinez et al. (2014) used unbaited sticky traps. Depending on the mating frequency of females it is possible that virgin and mated females orient along different flight paths with respect to the forest canopy. Virgin females may orient to the upper canopy in response to a light gradient and/or a male pheromone and mated females may orient to the lower bole in response to host volatiles.

Although trap trees can be effective for sampling $S$. noctilio they are expensive and labor intensive to use and can involve the use of herbicide. The development and use of a trap-lure system in place of trap trees has resulted in a 25-38\% cost reduction in Tasmania, and semiochemical-baited intercept traps are used in other parts of Australia where $S$. noctilio is not yet widely present (Bashford and Madden 2012; Carnegie and Bashford 2012). Although trap captures were low the results of this study suggest that although host trees vary in their perceived suitability to host-seeking females (Exp. \#1 but not Exp. \#2), the synthetic lures available commercially in North America are at least as effective as host material in Brazil. Multiple-funnel and panel traps were equally effective sampling $S$. noctilio in Brazilian pine plantations. Given that panel traps are less expensive, survey and detection programs may opt for this trap design. Finally, this study observed no differences in the capture of $S$. noctilio females in traps placed at 2 and $8 \mathrm{~m}$ height. Future studies should explore the role of visual stimuli in the orientation behavior of male and female $S$. noctilio as well as the contextdependence of visual and olfactory stimuli.

Acknowledgements We would like to acknowledge Luis Carlos Lima and Nassier Teodoro for assistance. This paper is part of grant \#2014/06585-3, São Paulo Research Foundation (FAPESP).

\section{References}

Allison JD, Redak RA (2017) The impact of trap type and design features on survey and detection of bark and woodboring beetles and their associates: a review and meta-analysis. Annu Rev Entomol 62:127-146. https://oi.org/10.1146/annurev-ento-010715-023516

Allison JD, Bhandari BD, McKenney JL, Millar JG (2014) Designs factors that influence the performance of flight intercept traps for the capture of longhorned beetles (Coleoptera: Cerambicidae) from the subfamilies Lamiinae and Cerambycinae. PLoS One 9(3):e93203. https://doi.org/10.1371/journal.pone.0093203

Ayres MP, Pena R, Lombardo JA, Lombardero MJ (2014) Host use patterns by the European woodwasp, Sirex noctilio, in its native and invaded range. PLoS One 9:e90321. https://doi.org/10.1371/journal. pone.0090321 PMID: 24675574 
Barnes BF, Meeker JR, Johnson W, Asaro C, Miller DR, Gandhi KJK (2014) Trapping techniques for siricids and their parasitoids (Hymenoptera: Siricidae and Ibaliidae) in the southeastern United States. Ann Entomol Soc Am 107:119-127

Bashford R (2008) The development of static trapping systems to monitor for wood-boring insects in forestry plantations. Aust For 71:236-241

Bashford R, Madden JL (2012) The use of kairomone lures for the detection of Sirex noctilio in susceptible Pinus radiata plantations in Australia. In: Slippers B, de Groot P, Wingfield MJ (eds) The Sirex woodwasp and its fungal symbiont, 1st edn. Springer, New York, pp 159-166

Beèche M, Lanfranco D, Zapata M, Ruiz C (2012) Surveillance and control of the Sirex Woodwasp: The Chilean experience. In: Slippers B, de Groot P, Wingfield MJ (eds) The Sirex woodwasp and its fungal symbiont, 1st edn. Springer, New York, pp 229-245

Billings RF, Upton WW (2010) A methodology for assessing annual risk of southern pine beetle outbreaks across the southern region using pheromone traps. In: Pye JM, Rauscher HM, Sands Y, Lee DC, Beatty JS (eds) Advances in threat assessment and their application to forest and rangeland management, 1st edn. USDA Forest Service, Pacific Northwest and Southern Research Stations, Portland, pp 73-86

Böröczky K, Zylstra KE, McCartney NB, Mastro VC, Tumlinson JH (2012) Volatile profile differences and the associated Sirex noctilio activity in two host tree species in the northeastern United States. J Chem Ecol 38:213-221

Brockerhoff EG, Jones DC, Kimberley MO, Suckling DM, Donaldson T (2006) Nationwide survey for invasive wood-boring and bark beetles (Coleoptera) using traps baited with pheromones and kairomones. For Ecol Manag 228:234-240

Carnegie AJ, Bashford R (2012) Sirex woodwasp in Australia: current management strategies, research and emerging issues. In: Slippers B, de Groot P, Wingfield MJ (eds) The Sirex woodwasp and its fungal symbiont, 1st edn. Springer, New York, pp 175-202

Carnegie AJ, Elderidge RH, Waterson DG (2005) History and management of Sirex wood wasp in pine plantations in new South Wales, Australia. N Z J For Sci 35:3-24

Cooperband MF, Böröczky K, Hartness A, Jones TH, Zylstra KE, Tumlinson JH, Masters GJ (2012) Maleproduced pheromone in the European woodwasp, Sirex noctilio. J Chem Ecol 38:52-62

Costello SL, Negron JF, Jacobi WR (2008) Traps and attractants for wood-boring insects in ponderosa pine stands in the Black Hills, South Dakota. J Econ Entomol 101:409-420

Coutts MP, Dolezal JE (1969) Emplacement of fungal spores by the woodwasp, Sirex noctilio, during oviposition. For Sci 15:412-416

Dodds KJ, de Groot P (2012) Sirex, surveys and management: challenges of having Sirex noctilio in North America. In: Slippers B, de Groot P, Wingfield MJ (eds) The Sirex woodwasp and its fungal symbiont, 1st edn. Springer, New York, pp 265-286

Dodds KJ, Ross DW, Daterman GE (2000) A comparison of traps and trap trees for capturing Douglas-fir beetle, Dendroctonus pseudotsugae (Coleoptera: Scolytidae). J Entomol Soc BC 97:33-38

Dodds KJ, de Groot P, Orwig DA (2010) The impact of Sirex noctilio in Pinus resinosa and Pinus sylvestris stands in New York and Ontario. Can J For Res 40(2):212-223

Dodds KJ, Allison JD, Miller DR, Hanavan RP, Sweeney J (2015) Considering species richness and rarity when selecting optimal survey traps: comparisons of semiochemical baited flight intercept traps for Cerambycidae in eastern North America. Agric For Entomol 17:36-47

Eager PT, Allen DC, Frair JL, Fierke MK (2011) Within-tree distributions of the Sirex noctilio Fabricius (Hymenoptera: Siricidae) - parasitoid complex and development of an optimal sampling scheme. Environ Entomol 40:1266-1275

Foelker CJ (2016) Beneath the bark: associations among Sirex noctilio development, bluestain fungi, and pine host species in North America. Ecol Entomol 41:676-684

Foelker CJ, Standley CR, Parry D, Fierke MK (2016) Complex ecological relationships among an assemblage of indigenous hymenopteran parasitoids, the exotic European woodwasp (Sirex noctilio; Hymenoptera: Siricidae), and a native congener. Can Entomol 148(5):532-542

Haavik LJ, Batista E, Dodds KJ, Johnson W, Meeker JR, Scarr TA, Allison JD (2014) Type of intercept trap not important for capturing female Sirex noctilio and S. nigricornis (Hymenoptera: Siricidae) in North America. J Econ Entomol 107(3):1295-1298

Haavik LJ, Dodds KJ, Allison JD (2015) Do native insects and associated fungi limit non-native woodwasp, Sirex noctilio, survival in a newly invaded environment? PLoS One 10:e0138516. https://doi.org/10.1371 /journal.pone.0138516 PMID: 26447845

Haavik LJ, Dodds KJ, Ryan K, Allison JD (2016) Evidence that the availability of suitable pine limits nonnative Sirex noctilio in Ontario. Agric For Entomol 18:357-366 
Haavik LJ, Dodds KJ, Allison JD (2017) Suitability of eastern pines for oviposition and survival of Sirex noctilio F. PLoS One 12(3):e0174532. https://doi.org/10.1371/journal.pone.0174532

Haugen DA, Bedding RA, Underdown MG, Neumann FG (1990) National strategy for control of Sirex noctilio in Australia. Aust For Grower 13(2):8

Hurley BP, Slippers B, Wingfield MJ (2007) A comparison of control results for the alien invasive woodwasp, Sirex noctilio, in the southern hemisphere. Agric For Entomol 9:159-171. https://doi.org/10.1111/j.14619563.2007.00340.x

Hurley BP, Garnas J, Cooperband MF (2015) Assessing trap and lure effectiveness for the monitoring of Sirex noctilio. Agric For Entomol 17(1):64-70

Hurley BP, Croft P, Verleur M, Wingfield MJ, Slippers B (2012) The control of the Sirex woodwasp in diverse environments: the south African experience. In: Slippers B, de Groot P, Wingfield MJ (eds) The Sirex woodwasp and its fungal symbiont, 1st edn. Springer, New York, pp 247-264

Iede ET, Penteado RCS, Filho WR (2012) The woodwasp Sirex noctilio in Brazil: monitoring and control. In: Slippers B, de Groot P, Wingfield MJ (eds) The Sirex woodwasp and its fungal symbiont, 1st edn. Springer, New York, pp 217-228

Jaenike J (1978) On optimal oviposition behavior in phytophagous insects. Theor Popul Biol 14:350-356

Johnson CW, Meeker JR, Ross WG, Petty SD, Bruce B, Steiner C (2013) Detection and seasonal abundance of Sirex nigricornis and Eriotremex formosanus (Hymenoptera: Siricidae) using various lures and trap trees in Central Louisiana, U.S. J Entomol Sci 48:173-183

Klasmer P, Botto E (2012) The ecology and biological control of the woodwasp Sirex noctilio in Patagonia, Argentina. In: Slippers B, de Groot P, Wingfield MJ (eds) The Sirex woodwasp and its fungal symbiont, 1st edn. Springer, New York, pp 203-216

Liebhold AM, Tobin PC (2008) Population ecology of insect invasions and their management. Annu Rev Entomol 53:387-408

Madden JL (1971) Some treatments which render Monterey pine (Pinus radiata) attractive to the wood wasp Sirex noctilio F. Bull Entomol Res 60:467-472

Madden JL (1974) Oviposition behavior of the woodwasp Sirex noctilio F. Aust J Zool 22:341-351

Madden JL (1988) Sirex in Australasia. In: Berryman AA (ed) Dynamics of forest insect populations, 1 st edn. Plenum Press, New York, pp 407-429

Madden JL, Coutts MP. (1979) The role of fungi in the biology and ecology of woodwasps (Hymenoptera: Siricidae). Insect-fungus Symbiosis: 165-174

Madden JL, Irvine CJ (1971) The use of lure trees for the detection of Sirex noctilio in the field. Aust For 35: 164-166

Martínez AS, Villacide J, Fernández Ajó AA, Martinson SJ, Corley JC (2014) Sirex noctilio flight behavior: toward improving current monitoring techniques. Entomol Exp Appl 152(2):135-140

Mayhew PJ (1997) Adaptive patterns of host-plant selection by phytophagous insects. Oikos 79:417-428

McIntosh RL, Katinic PJ, Allison JD, Borden JH, Downey DL (2001) Comparative efficacy of five types of trap for woodborers in the Cerambycidae, Buprestidae and Siricidae. Agric For Entomol 3:113-120

Mercader RJ, McCullough DG, Bedford JM (2013) A comparison of girdled ash detection trees and baited artificial traps for Agrilus planipennis (Coleoptera: Buprestidae) detection. Environ Entomol 42:1027-1039

Miller DR, Crowe CM, Barnes BF, Gandhi KJK, Duerr DA (2013) Attaching lures to multiple-funnel traps targeting saproxylic beetles (Coleoptera) in pine stands: inside or outside funnels? J Econ Entomol 106(1): 206-214

Morgan FD, Stewart NC (1966) The biology and behavior of the woodwasp Sirex noctilio F. in New Zealand. Trans Roy Soc NZ Zool 7:195-204

Myers JH, Simberloff D, Kuris AM, Carey JR (2000) Eradication revisited: dealing with exotic species. Trends Ecol Evol 15:316-320

Neumann FG, Minko G (1981) The Sirex wood wasp in Australian radiata pine plantations. Aust For 44:46-63

Neumann FG, Harris JA, Kassaby FY, Minko G (1982) An improved technique for early detection and control of the Sirex wood wasp in radiata pine plantations. Aust For 45:117-124

Penteado SRC, Iede ET, Reis-Filho W (2002) Manual para o controle da vespa-da-madeira em plantio de pinus. Embrapa CNPF, Colombo

Rabaglia R, Duerr D, Acciavatti R, Ragenovich I (2008) Early detection and rapid response for non-native bark and ambrosia beetles. USDA Forest Service Forest Health Protection, Washington DC

Rawlings GB, Wilson NM (1949) Sirex noctilio as a beneficial and destructive insect of Pinus radiata in New Zealand. N. Z J For 6(1):20-29

Ryan K, Hurley BP (2012) Life history and biology of Sirex noctilio. In: Slippers B, de Groot P, Wingfield MJ (eds) The Sirex woodwasp and its fungal symbiont, 1st edn. Springer, New York, pp 15-30 
Ryan K, De Groot P, Nott RW, Drabble S, Ochoa I, Davis C et al (2012) Natural enemies associated with Sirex noctilio (Hymenoptera: Siricidae) and S. nigricornis in Ontario, Canada. Environ Entomol 41:289-297. https://doi.org/10.1603/EN11275 PMID: 22507001

Sarvary MA, Cooperband MF, Hajek AE (2015) The importance of olfactory and visual cues in developing better monitoring tools for Sirex noctilio (Hymenoptera: Siricidae). Agric For Entomol 17:29-35

Simpson RF (1976) Bioassay of pine oil components as attractants for Sirex noctilio (Hymenoptera: Siricidae) using electroantennogram techniques. Entomol Exp Appl 19:11-18

Simpson RF, McQuilkin RM (1976) Identification of volatiles from felled Pinus radiata and the electroantennograms they elicit from Sirex noctilio. Entomol Exp Appl 19:205-213

Slippers B, de Groot P, Wingfield MJ (2012) The Sirex woodwasp and its fungal symbiont: research and management of a worldwide invasive pest. Springer, New York

Sokal RR, Rohlf FJ (1981) Biometry: the principles and practice of statistics in biological research, 2nd edn. W. H. Freeman Company, New York

Thomson JN (1988) Evolutionary ecology of the relationshp between oviposition preference and performance of offspring in phytophagous insects. Entomol Exp Appl 47:3-14

Zylstra KE, Mastro VC (2012) Common mortality factors of woodwasp larvae in three northeastern United States host species. J Insect Sci 12:1-8

Zylstra KE, Dodds KJ, Francese JA, Mastro V (2010) Sirex noctilio in North America: the effect of stem injection timing on the attractiveness and suitability of trap trees. Agric For Entomol 12:243-250 